\title{
Mass Migration and Uprisings in Arab Countries: An Analytical Framework
}

\author{
Philippe Fargues
}

\begin{abstract}
Is there a relationship between political movements and population movements in the Arab world? More specifically, are the uprisings that spread throughout Arab countries starting at the end of 2010 linked in any way with the international migration of their citizens? This paper first reviews the common determinants of revolt and emigration and addresses the question of how the two phenomena are partly rooted in the deep demographic changes Arab populations are currently going through. The paper then reviews the migratory outcomes of revolt both in terms of voluntary and forced migration. It finally explores diasporas' impact on homeland politics, or - more preciselythe role played by national expatriates in the revolts unfolding in their homelands, in particular through political remittances.
\end{abstract}

\section{Introduction}

Is there any relationship between political movements and population movements in the Arab world? More specifically, are the uprisings that, from the end of 2010, spread through Arab countries, linked in any way with the international migration of their citizens?

It should be noted, here from the outset, that the links between revolt and migration, if they exist, can neither be unidirectional nor necessary. Indeed, while major uprisings happened in countries with strong emigration traditions (Tunisia, Egypt, Syria, Yemen...), others took place in countries where immigration outweighs emigration (Libya and Bahrain). Moreover, some countries that are major migrant senders did not experience any large-scale uprisings (Jordan, Lebanon, Morocco, Algeria...) and the same applies to countries that are major receivers (the GCC states apart from Bahrain).

The two phenomena can, however, be linked in many ways (Figure 9.1). Indirect links may be found by which popular revolts and mass migration can be shown to share certain determinants. Direct links also exist in both directions. Indeed, revolts have generated massive flows of, mostly forced, 


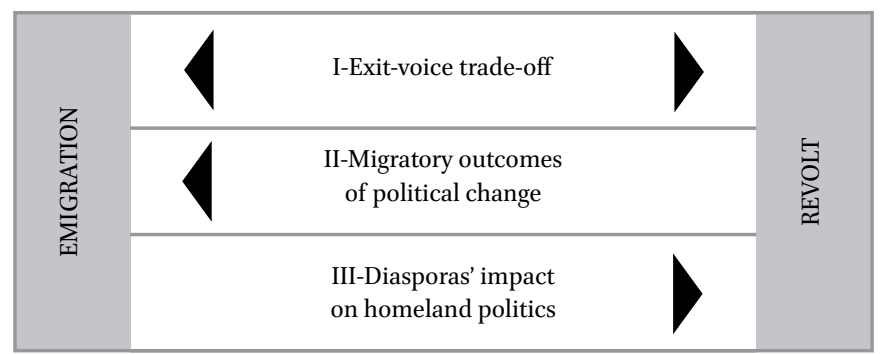

FIGURE 9.1 Framework of interaction between emigration and revolt SOURCE: AUTHOR

migration and more must be expected; and migration is, likewise, capable of affecting revolts.

The first section of this chapter will review the common determinants of emigration and revolt and show that both exit and voice respond to the deep demographic changes Arab populations are currently experiencing. The second section will describe the migratory outcomes of revolt both in terms of voluntary and forced migration. The third section will explore the impact of diasporas on homeland politics, and more precisely the role played by national expatriates with regard to the revolts unfolding in their homelands.

Photographs taken in large Arab cities suggest that two crowds, demonstrators gathering for mass protests and visa applicants lining up at foreign consulates, have at least one thing in common: both are comprised predominantly of young men. Would then some of the factors that pull young men on to the streets for demonstrations be the same as those that push them into international migration? Certainly — as we shall see-'relative deprivation' has been used to explain revolt and migration and the two phenomena are tied to a single model of 'exit or voice'. After reviewing this evidence, we will advance the claim that demographic change is a key factor linking revolt and migration.

Relative deprivation is the feeling experienced by people who discover that their lot is not as good as that of their peers. Comparing themselves to their 'reference group', they have the sentiment that they are deprived of a material or a symbolic object they believe they have a right to have, or they expect more than they can actually achieve (Merton, 1938). Transposed from the individual to the social level of groups and social classes, relative deprivation becomes a driver of collective violence (Gurr, 1970). Revolution is most likely to take place 
when 'men become angered because they acquire new or intensified expectations which cannot be satisfied by means at their disposal' (Gurr, 1973, 365). And certainly much of what has happened in Arab countries since the end of 2010 can be understood as discontent generated by 'the perceived gap between expectations and capability' (Gurr, 1973, 365).

Not only can relative deprivation trigger collective violence, it can also motivate individuals' international migration. People who judge that they do not, at home, receive rewards commensurate with their capacities may consider leaving their own country to find a country where they think these rewards are available. Emigration is influenced by 'how individuals evaluate what they have (satisfaction) and what they do not have (deprivation) [...] the decision by households to send migrants to foreign labour markets is influenced by their initial perceived relative deprivation within the reference group' (Stark and Taylor, 1989, 3-4). Typically, transnational networks spanning origin and destination countries are, at the same time, the reference group that make migration desirable, and the source of information on distant labour markets and the social capital that make it possible.

Both revolt and migration respond to the same sentiment of relative deprivation and take place when frustration rises and resignation ceases to be an option. They are a perfect illustration of Hirschman's model of exit or voice as opposed to loyalty (Hirschman, 1970). A relevant question in the present case will be to ask whether revolt and migration are substitutes or possible complements, whether there is a trade-off by which people who exit lose their voice, or whether they keep 'voicing' but through other channels and in another fashion; put in other terms - do emigrants remain political actors in their homelands?

What creates relative deprivation in contemporary Arab societies leading to exit or voice among the young? Many reasons residing in the social and political systems of Arab countries have been put forward in the lavish literature on the Arab Spring. In what follows, we confine ourselves to recalling what has been developed elsewhere. Demographic change is a key contextual—or 'predisposing', to borrow from epidemiology — factor that created fertile ground for both migration and revolt. More precisely, we argue that a lack of opportunities combined with a demographic bulge among the young accounts for many migratory and political processes at play in the Arab world today (Fargues, 2012).

In a nutshell, our argument is based on the fact that the decline of birth rates in Arab populations came late (with a few exceptions, it did not occur significantly before the mid-1980s) but steady (more so in the Maghreb than in the Mashreq). In the early 2010s, the largest generations ever born in these countries were aged between 20 and 35, a phenomenon commonly described as a 'youth bulge' (Figure 9.2). In the case of Arab populations, not only is 


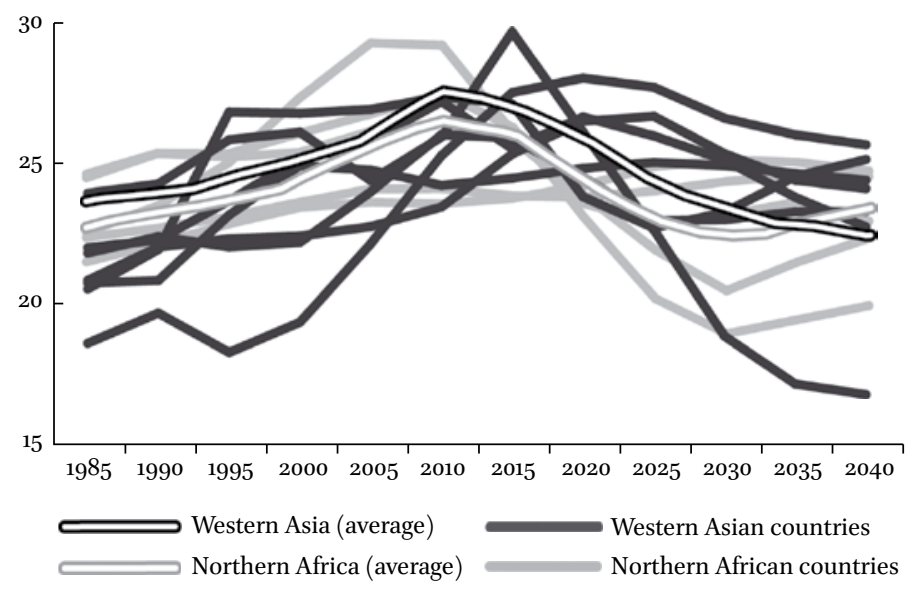

FIGURE 9.2 The youth bulge in Arab countries

Note: Western Asian countries include Iraq, Jordan, Lebanon, Libya, Palestine, Syria, Yemen. Northern African countries include Algeria, Egypt, Mauritania, Morocco, Sudan, Tunisia.

SOURCE: AUTHOR'S CALCULATION FROM UNITED NATIONS, POPULATION DIVISION, WORLD POPULATION PROSPECTS: THE 2012 REVISION HTTP://ESA .UN.ORG/WPP/UNPP/PANEL_INDICATORS.HTM.

intra-group competition more acute than ever before, it is also exacerbated by a radical change in the status of young adults.

Indeed, with now low birth rates and dominant patterns of late marriage, family responsibilities - that until recently were the common lot of young Arab adults-have been lifted: at 30, a typical citizen of an Arab country is not yet married and has no children. We have described this phenomenon elsewhere as the birth of the individual (Fargues, 2000). Such a change is particularly meaningful in societies comprised of families and clans with an immemorial tradition of negating the individual. It provides unprecedented personal freedom of movement and opens the way to mobility and risk-taking.

Moreover, the demographic transition has been paralleled by a steady increase in the level of education, with the gross enrolment ratio at tertiary level reaching 33 per cent after 2010, a level typical of upper-middle-income countries (World Bank, 2015). Rising education levels naturally translate to rising expectations. But due to governance failures (among other factors) young Arab adults' expectations are cruelly frustrated, making them a generation kept in waiting (Dhillon et al., 2009). Economically, expectations are barred by unemployment, underemployment and low rewards for those skills that characterise local labour markets. On the eve of the Arab revolts, the rate of unemployment amongst Arab youth was close to 30 per cent-that is, more than twice the world average of 14 per cent (UNDP, 2009; Handoussa, 2010). Unemployment, 
TABLE 9.1 Migrants originating from Arab Mediterranean countries, by region of residence, ca 2012.

\begin{tabular}{|c|c|c|c|c|c|c|c|}
\hline \multirow{2}{*}{$\begin{array}{l}\text { Country of } \\
\text { origina }^{a}\end{array}$} & \multirow{2}{*}{$\begin{array}{l}\text { Total } \\
\text { population }\end{array}$} & \multicolumn{4}{|c|}{ Migrants by region of destination } & \multirow{2}{*}{$\begin{array}{l}\text { Migrants \% } \\
\text { population }\end{array}$} & \multirow{2}{*}{$\begin{array}{l}\text { Migrants in } \\
\text { the EU \% }\end{array}$} \\
\hline & & $\begin{array}{l}\text { European } \\
\text { Union }\end{array}$ & Arab states & $\begin{array}{l}\text { Rest of the } \\
\text { world }\end{array}$ & Total & & \\
\hline Mauritania & $3,796,141$ & 28,807 & 24,000 & 169,500 & 222,307 & $5.9 \%$ & $13 \%$ \\
\hline Morocco & $32,5^{21,143}$ & $3,056,109$ & 214,438 & 101,432 & $3,371,979$ & $10.4 \%$ & $91 \%$ \\
\hline Algeria & $38,481,705$ & 877,398 & 11,209 & 73,243 & $961,85^{\circ}$ & $2.5 \%$ & $91 \%$ \\
\hline Tunisia & $10,874,915$ & 911,400 & 154,900 & 31,900 & $1,098,200$ & $10.1 \%$ & $83 \%$ \\
\hline Libya & $6,154,623$ & 66,344 & 9,824 & 24,397 & 100,565 & $1.6 \%$ & $66 \%$ \\
\hline Egypt $^{b}$ & $80,721,874$ & 224,122 & $4,783,800$ & 404,945 & $5,412,867$ & $6.7 \%$ & $4 \%$ \\
\hline Lebanon & $4,647,079$ & 148,717 & 162,663 & 290,900 & 602,280 & $13.0 \%$ & $25 \%$ \\
\hline Syria $^{c}$ & $21,889,682$ & 247,880 & $2,191,313$ & $1,823,305$ & $4,262,498$ & $19.5 \%$ & $6 \%$ \\
\hline Jordan & $7,009,444$ & 33,066 & 218,149 & 88,540 & 339,755 & $4.8 \%$ & $10 \%$ \\
\hline Palestine $^{\mathrm{d}}$ & $4,218,771$ & 14,627 & 844,063 & 13,234 & 871,924 & $20.7 \%$ & $2 \%$ \\
\hline Total & $210,315,377$ & $5,608,470$ & $8,614,359$ & $3,021,396$ & $17,244,225$ & $8.2 \%$ & $33 \%$ \\
\hline
\end{tabular}

SOURCES: FOR THE EU-EUROSTAT, EXCEPT FOR MOROCCANS (CONSULAR RECORDS); ARAB STATES AND OTHER REGIONS-ESTIMATES PROVIDED BY ORIGIN COUNTRIES.

a Origin defined as country of birth (preferred) or country of nationality (second best).

b Egyptian temporary migrants in the Gulf States $(2,283,800)$ and Libya $(2,000,000$ as estimated by the Egyptian government - the number of Egyptian migrants still in Libya in early 2015 is believed to have been less than 100,000).

c Syrian residents by region + refugees (in the Arab states and Turkey) and new asylum seekers (EU) from March 2011 until March 2015.

d Palestinian UNWRA refugees in Jordan $(1,979,580)$ who have Jordanian citizenship are not included.

which until the 1980 s was limited and confined to illiterate segments of the population, has now become the lot of a large proportion of young, educated people and university graduates. Politically, young Arab adults' expectations are negated by authoritarian regimes.

Frustration calls for a response. In the non-democratic, repressive context of Arab countries, exit came before voice. Emigration from Arab countries (except from the large oil and gas exporters of the Gulf and Libya) has been intense over the last two to three decades. Stocks of current emigrants represent 8.7 per cent of the aggregate population of Arab Mediterranean states (table 9.1), which is almost three times the world average. Comparable levels 
must be expected for non-Mediterranean Arab states (Yemen, Sudan...) for which reliable data are not available.

Just as importantly, the desire to emigrate is now peaking. In Tunisia, the country where the Arab revolts started in 2010, a large, national, representative survey of young people $\left(15^{-29}\right.$ years old), repeated at three points in time, revealed an unexpectedly high (and increasing) wish to emigrate: in 1996, 22 per cent of the young people interviewed expressed such a desire; in 2000 the figure was 45 per cent, and in 2005, 76 per cent (Fourati, 2008). These 'desires' are not a predictor of actual mobility (after all, a wish does not necessarily become reality), but they do constitute a revelation of remarkable discontent among the young.

\section{3} Migratory Outcomes of Revolt

Revolts have already brought about considerable movements of mostly forced migration, but also some fresh outbreaks of voluntary, economic migration.

There have been two cases of mass displacements: Libya and Syria. They differ greatly in terms of nature and magnitude. The Libyan revolution that overturned the Gaddafi dictatorship in 2011 displaced more than 1.1 million persons, including 422,00o Libyans seeking temporary refuge abroad and 706,000 migrant workers, who left the country; 43 per cent of these reached Tunisia and $3^{2}$ per cent Egypt (IOM, 2012). While it is believed that most Libyan refugees returned to Libya once the regime had been overthrown, not much is known about the migrant workers who left the country in 2011. Many will have either returned to Libya or have been replaced by new migrants, in particular from Tunisia and Egypt. At the time of writing, the numbers of migrant workers in Libya and of refugees waiting to be smuggled to Europe are unknown. One can assume that, with the collapse of the Libyan government and the development of rival militias, the exploitation, abuse, detention and killings orchestrated by the Islamic State in Iraq and the Levant (ISIL) will encourage departures from Libya among newly arrived migrants (Grange and Flynn, 2015; Government of the Netherlands, 2014).

In Syria, the protests that soon turned into civil conflict triggered an implacable spiral of repression and protest. At the time of writing (April 2015) 7-10 million people have been forcibly removed from their homes, including more than 4 million refugees and perhaps a larger number of internally displaced persons (UNHCR, 2015). To these Syrian refugees, one must add all the non-Syrians (Iraqis and Palestinians) who were refugees in Syria and who fled to become second order refugees in other countries, in particular Lebanon. 
At the time of writing large numbers in need of protection continue to pour out of Syria.

The bulk of Syria's refugees are sheltered among four of its five neighbours: Lebanon (1.2 million), Turkey (1.8 million), Jordan $(630,000)$ and Iraq $(220,000)$. Israel, which is at war with Syria, has kept its borders closed. Not only do massive waves of refugees exert unbearable pressure on the economy of the host nation, they also bring with them the risk of political destabilisation. This is particularly the case in Lebanon where Syrian refugees, almost all belonging to the Sunni branch of Islam, risk setting alight dormant tensions between Lebanese religious communities. In a country where history has shown that refugees may wait a lifetime and still never return home, there is a fear that not all the refugees will return to Syria when the conflict ends. The fragile equilibrium between communities would then be threatened.

Other Syrian refugees have reached more distant destinations in the Arab world (135,000 in Egypt) and in the European Union (ca 220,000). Many of those who eventually reached Europe were unable to get a visa to travel regularly and safely to their destination. Instead, they undertook a long journey through Jordan, Egypt and then Libya from where they were smuggled across the Mediterranean at the risk of their lives. Among the 250,000 migrants smuggled by sea to Italy from January 2012 until April 2015, more than 55,000 were Syrians (Fargues and Di Bartolomeo, 2015).

Less spectacular than mass flight induced by war and civil conflict is the modest increase in labour migration that has been observed in the wake of revolts, in particular from Tunisia. In the first half of 2011 an upsurge of irregular migration to Italy was recorded, with some 25,000 unauthorised migrants from Tunisia reaching Italy and Malta by sea. This sudden, short-lived movement can be explained by a conjunction of facts: Tunisian border police operations broke down during the revolution and-as control over departures was relaxed - a large pool of would-be migrants were stranded, waiting for an opportunity to leave the country; and migratory pressure increased as Tunisia had to accommodate hundreds of thousands of migrant workers fleeing Libya, including many Tunisians (Boubakri, 2013).

One might expect that revolts will affect migration in the medium term, but it is not clear how. There might be an increase in the emigration of citizens or the return of expatriates, depending upon the achievements of governments put in place after the revolts. At the time of writing, it seems likely that emigration will continue for some time. Indeed, revolts may have so far created more incentives than deterrents to emigration.

A survey conducted amongst young Egyptians in 2013 (during the short presidency of the Muslim Brotherhood's Mohamed Morsi) helps to identify 


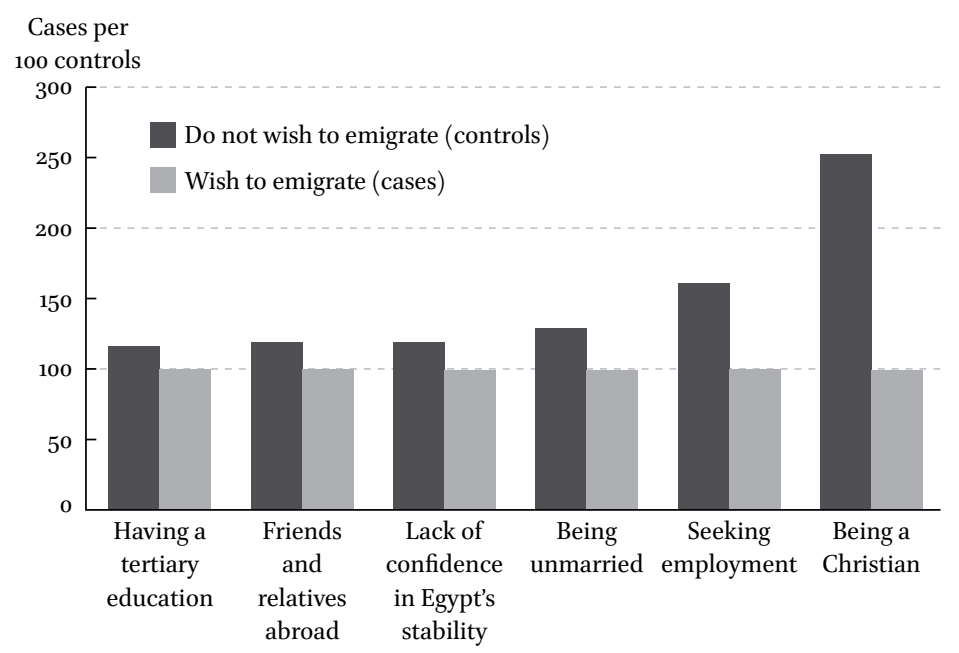

FIGURE 9.3 Drivers of the intention to emigrate among young Egyptians in 2013 SOURCE: AMER AND FARGUES, 2014.

the main drivers of the intention to emigrate, as shown in Figure 9.3 (Amer and Fargues, 2014; see also Pitea and Abdel Mohsen, 2011). A case-control was adopted and characteristics that were found to be significantly more frequent among cases (those who wished to emigrate) than controls (those who did not wish to emigrate) were considered drivers of emigration. A number of drivers are not directly linked to the revolution, including having a university education, being unmarried, seeking (better) employment and being exposed to others' migration through friends or relatives living abroad. Other drivers are more susceptible to be linked to the post-revolutionary situation, in particular religion and the lack of confidence in Egypt's stability. Being a Christian was found to be a key driver of the intention to emigrate. Are Egyptian Christians more inclined than Muslims to emigrate because they share more of the features of those young people who wish to emigrate, such as a higher education or friends and relatives abroad? Or is it that Christians feel more insecure at home than do Muslims? The survey does not help to disentangle the two.

As the same factors explain both emigration and revolt could it be that emigrants, or some of them, played a direct role in revolts and the process of political change that followed? Put in other terms, was exit, sometimes, transformed into voice? This could happen through different channels: the return 
of migrants or exiles to take part in the revolution, their participation in elections in their homeland, or their contribution to disseminating ideas that, in turn, affect political developments, often referred to as political remittances.

\subsection{Return of Exiles}

From the outset it must be said that the revolts in Arab countries were conducted from within by local people and owe very little to the direct involvement of diasporas. It is true that several high-profile figures of the Arab Spring have a history of migration or exile. This is the case in Tunisia. There, the winner of the first post-revolution presidential election, Moncef Marzouki, and the leader of the Islamist party Ennahda, which won the 2011 parliamentary elections, Rached Ghannouchi, both returned from a long exile in Europe just days after former President Ben Ali was ousted.

In Egypt several popular figures of the Revolution were at the time established abroad. Take Mohamed Elbaradei, the former Director General of the International Atomic Energy Agency and overt opponent to President Mubarak; or Wael Ghonim, the internet activist, whose Facebook page-run from Dubai-provided, in real time, key information on developments during the Midan Tahrir demonstrations in Cairo. In the case of Syria, the main opposition institution, the Syrian National Council, was created abroad (in Istanbul in 2011) by exiles of the Muslim Brotherhood and other political movements.

In the other countries of the Arab Spring - in particular Libya, Yemen and Bahrain-no eminent figure of the uprisings seems to have come from the diaspora and such figures' experience abroad was at best a few years spent overseas as students or civil servants.

\subsection{External Voting}

The emigration from Arab countries started more than a hundred years ago and gained momentum in the last quarter of the twentieth century, resulting in the formation of Arab diasporas in Europe, the Americas, Africa and Oceania. For decades, Arab states paid little or no attention to those who had left the country and to their descendants. In post-independence years several states even showed distrust towards communities they suspected as serving as hotbeds of plotters and political opponents.

In roughly the late 1980 s and early 1990s, Arab states relinquished statecentred, planned economies for market economies and adopted International Monetary Fund inspired policies of 'structural adjustment': at this point diasporas started to be regarded in a different way. While governments continued to see destination countries (the West as well as the Gulf) as havens for their opponents, they had become sufficiently strong not to feel threatened by their émigrés and exiles. On the contrary, they began to see these émigrés as a 
potential resource for the nation: first as a source of income; then, of cultural pride; and finally, of political support.

Specific institutions were established by each Arab state with a mandate to fostering transnational links with their diasporas. These institutions were concerned with economic links in the first instance. Draining money from Arab expatriates (workers' remittances sent to families left behind, entrepreneurs' investments in the national economy, etc.), making use of their skills and tapping their business networks could make a substantial contribution to development efforts in origin countries. Cultural links came later. Reviving a sense of belonging to the homeland among migrants and especially their sons and daughters born in the diaspora was cultural diplomacy. But perhaps more importantly, it could sustain such individuals' motivation to remit and invest money in the homeland.

Eventually, political links were sought. Arrangements enabling expatriate nationals to exercise their voting rights from abroad were made by a number of Arab states, including Algeria, Morocco and Tunisia (Collyer, 2014; Jaulin, 2014). Morocco went a step further with its constitution of 2011, granting eligibility rights in the kingdom to expatriate nationals. Another significant step towards the political integration of the descendants of migrants has been the recognition of dual citizenship by a number of countries and the granting of the right to transmit nationality to children born of a native woman and a foreign father (Tunisia, 1963; Egypt, 2004; Algeria, 2005; and Morocco, 2007).

\subsection{Political Remittances}

In a variety of locations, from the neighbourhood to the workplace, migrants mix with natives. They are, often unconsciously, exposed to the ideas and models of their host societies, which are new to them. With the passing of time, they adopt some of these values and models, which they unwittingly transfer to their home society. Direct communication with relatives and friends established abroad, as well as mass communication through media paying special interest to countries where the diaspora lives, will-therefore-expose nonmigrants in origin countries to ideas and models typical of societies that they have never lived in. This mechanism, described as 'social remittances' (Levitt, 2001), is thought to apply to a wide range of domains, including political values (Docquier et al., 2011; Tabar, 2014).

What political values migrants convey will depend upon the political environment of their destination country. Arab migrants have two main destinations, the Gulf States and the West. The polity migrants find when they reach their destination is either more conservative than that of their country of origin, or more liberal, according to whether they go to the Gulf or to the West. Schematically, one might hypothesise that a dominant pattern of emigration to 

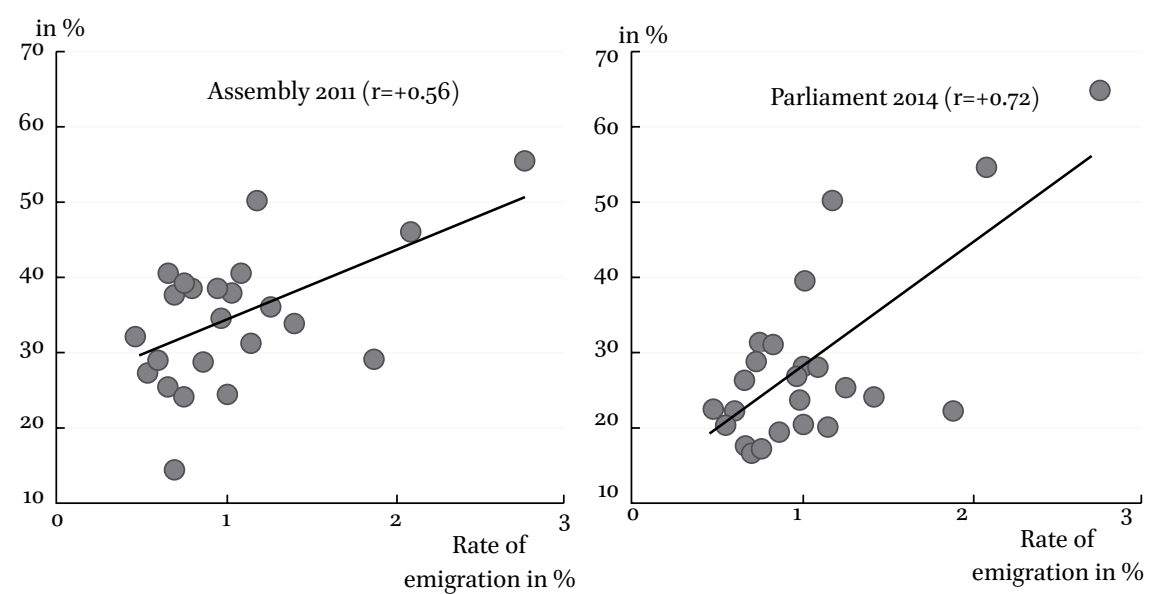

FIGURE 9.4 Rates of emigration and voting for Ennahda in the Tunisian elections of 2011 and 2014, at governorate level

SOURCE: AUTHOR'S CALCULATIONS.

the Gulf will translate into conservatism spreading in the origin communities of migrants; while a dominant pattern of emigration to the West will disseminate progressivism and democratic values in these same communities.

Do the contrasting post-revolution developments in Egypt and Tunisia bring any credit to this argument? In both countries popular uprisings occurred in 2011, but they ended very differently. In Tunisia, Islamist and secular parties engaged in a democratic process resulting in a peaceful changeover of political power and the adoption of a resolutely progressive constitution. In Egypt the first free election of a president soon led to an Islamist dictatorship, which did not last long and which was replaced by authoritarian rule. This new authoritarian rule is in many regards comparable to the regime overthrown in the revolution, except that the new authoritarian ruler was freely elected by an overwhelming majority.

The political remittances hypothesis sheds light on differences, not only between countries, but also within a given country. For example, in Tunisia there is Ennahda, the 'Renaissance' party influenced by the Egyptian Muslim Brotherhood, which had been banned for more than two decades under the Ben Ali dictatorship. It was reinstated in the early days of the revolution. In both the constituent assembly election of 2011 and the parliamentary election of 2014, a strong positive space-correlation is observed between the score of Ennahda and the rate of emigration, at governorate level (figure 9.4). It might be that voting for Ennahda and emigrating are responses to the same factors, from poverty to unemployment. It might also be that emigration has fostered a culture of protest in the governorates of origin of migrants. Indeed, Tunisian 
migrants are mostly destined for France and Italy - two countries with an established tradition of protest. Because the party had been banned by the ousted dictator, voting for Ennahda became a natural form of protest.

\section{5}

\section{Conclusion}

Expatriation and political protest are both rooted in deprivation and discontent and in the notion that life could be better, either in another place or at home under another regime. Moreover, they work in synergy, as expatriation can be the result of protest failing to achieve its goals and protest can find inspiration in ideas and models gathered abroad by migrants. So, what does the future look like? Migration and revolt have an age: both are typical of young adults. As a result of long-term demographic trends, young adults in Arab countries are now to be counted in greater numbers than ever before (the 'youth bulge'), and for the first time they are free of family constraints ('the birth of the individual'). Their availability with regards to mobility and to risktaking will not suddenly end.

Voluntary, economic migration, or the reasons behind it, will-indeedcontinue. Unless a miraculous economic upturn keeps the mass of young people at home, dreaming of a future fit for their expectations, many will keep trying their luck abroad. Where they will go is less clear. Apart from the most talented, Arab migrants are likely to find more and more hurdles barring their way to traditional destinations. The Gulf States are committed to replacing expatriates with nationals and the West is slowly exiting its worst unemployment crisis since the Great Depression of the 1930s. Exit may no longer fill the role of safety valve that it has for decades. Will, then, voice be the only choice left? The Arab awakening has not finished speaking. But, at the time of writing, one must acknowledge that revolt has produced a surge in departures.

Forced migration has gained unprecedented momentum in the Arab Middle East, which is by far the world's largest producer and receiver of refugees. Refugee movements must be expected to continue, since the restoration of peace and security-which would stop the exoduses of families fleeing war and persecution - is not in sight at the time of writing. Where they will find shelter is unclear. Jordan and Lebanon have now closed their borders to the entry of new refugees and put in place more stringent conditions that must be met if those already there are to stay. Turkey may follow, while Europe is not keen to fling open its doors to refugees. The result might be an increase in the number of internally displaced persons. It is doubtful, however, that forced migration could rekindle the dynamics of the Arab Spring, for internally displaced persons are uprooted people who lack the necessary territorial base for revolt. 


\section{References}

Amer, M. and P. Fargues (2014) Labour Market Outcomes and Egypt's Migration Potential, EUI/RSCAs Working Papers, MPC Series No. 55, http://cadmus.eui.eu//handle/ 1814/17794 (accessed on 6 April 2016).

Boubakri, H. (2013) Revolution and International Migration in Tunisia, MPC Research Report No. 4, http://www.migrationpolicycentre.eu/docs/MPC-RR-2013-04.pdf (accessed on 6 April 2016).

Collyer, M. (2014) 'A Geography of Extra-Territorial Citizenship: Explanations of External Voting', Migration Studies, 2(1), pp. 55-72, DoI: 10.1093/migration/mnsoo8.

Dhillon, N., P. Dyer and T. Yousef (2009) 'Generation in Waiting: An Overview of School to Work and Family Formation Transitions', in Dhillon, N. and T. Yousef (eds.) Generation in Waiting: The Unfulfilled Promise of Young People in the Middle East (Washington D.C.: Brookings Institution Press), pp. 11-35, http://www.brookings.edu/ / media/Files/Press/Books/20og/agenerationinwaiting/agenerationinwaiting_chap ter.pdf (accessed on 6 April 2016).

Docquier, F., E. Lodigiani, H. Rapoport and M. Schiff (2011) Emigration and Democracy, IZA Discussion Paper Series No. 5496 (Bonn: Institute for the Study of Labour), http://ftp.iza.org/dp5496.pdf (accessed on 6 April 2016).

Fargues, P. (2000) Générations Arabes. L'Alchimie du Nombre (Paris: Fayard).

Fargues, P. (2012) 'Demography, Migration and Revolt in the South of the Mediterranean', in C. Molini and O. Roy (2012).

Fargues, P. and A. Di Bartolomeo (2015) Drowned Europe, Policy Brief No. 5 (FI: European University Institute), DOI: 10.2870/417003.

Fourati, H. (2008) Consultations de la Jeunesse et Désir d'Emigrer Chez les Jeunes en Tunisie 1996-2005, CARIM Analytic and Synthetic Notes No. 47 (FI: European University Institute), http://cadmus.eui.eu/handle/1814/10091 (accessed on 6 April 2016).

Government of the Netherlands, Ministry of Foreign Affairs (2014) Libya: Militias, Tribes and Islamists (Amsterdam: Ministry of Foreign Affairs), http://www.govern ment.nl/documents-and-publications/reports/2014/12/20/libya-militias-tribes-and -islamists.html (accessed on 6 April 2016).

Grange, M. and M. Flynn (2015) Immigration and Detention in Libya, (Geneva: Global Detention Project), http://www.globaldetentionproject.org/fileadmin/docs/Libya _report.pdf (accessed on 6 April 2016).

Gurr, T.R. (1970) Why Men Rebel (Princeton: Princeton University Press).

Gurr, T.R. (1973) 'The Revolution, Social-Change Nexus: Some Old Theories and New Hypotheses', Comparative Politics, 5 (3), pp. 359-392.

Handoussa, H. (2010), Egypt Human Development Report 2010: Youth in Egypt, Building our Future (Cairo: United Nations Development Programme and the Institute of 
National Planning), http://www.undp.org.eg/Portals/o/NHDR\%202010\%2oenglish .pdf (accessed on 6 April 2016).

Hirschman, A.O. (1970) Exit, Voice, and Loyalty. Responses to Decline in Firms, Organizations, and States (Harvard: Harvard University Press).

International Organization for Migration (IOM) (2012) Humanitarian Response to the Libyan Crisis, February-December 2011 Report (Geneva: IOM), http://publications .iom.int/bookstore/free/final_mena_10_months_compressed.pdf (accessed on 6 April 2016).

Jaulin, T. (2014) 'Géographie du Vote à Distance: l'Election Tunisienne de 2011 à l'Etranger', L'Espace Politique, 2(23), DoI: 10.4000/espacepolitique.3099.

Levitt, P. (2001) The Transnational Villagers (Berkeley and Los Angeles: University of California Press).

Merlini, C. and O. Roy (eds.) (2012) Arab Society in Revolt (Washington D.C.: Brookings Institution Press), pp. 17-46.

Merton, R.K. (1938) 'Social Structure and Anomie', American Sociological Review, 3(5), pp. $672-682$.

Pitea R. and R. Abdel Mohsen (2011) Egypt after January 25: Survey of Youth Migration Intention, (Cairo: IOM), http://www.egypt.iom.int/Doc/IOM\%20\%282011\%29\%20 Egypt\%2oafter\%2oJanuary\%2025\%2oSurvey\%2oof\%2oYouth\%2oMigration\%2o Intentions.pdf (accessed on 6 April 2016).

Stark O. and E. Taylor (1989) 'Relative Deprivation and International Migration', Demography, 26(1), pp. 1-14.

Tabar, P. (2014) "Political Remittances": The Case of Lebanese Expatriates Voting in National Elections', Journal of Intercultural Studies, 35(4), pp. 442-460.

UNDP (United Nations Development Programme) (2009) Arab Human Development Report 20og: Challenges to Human Security in the Arab Countries (New York: United Nations Publications), http://www.arab-hdr.org/contents/index.aspx?rid=5 (accessed on 6 April 2016).

UNHCR (United Nations High Commissioner for Refugees UNHC) (2015) Syria Regional Refugee Response, Inter-agency Information Sharing Portal, http://data.unhcr .org/syrianrefugees/regional.php (accessed on 6 April 2016).

World Bank (2015) Gross enrolment ratio, tertiary, both sexes (\%), World Development Indicators, http://data.worldbank.org/indicator/SE.TER.ENRR (accessed on 6 April 2016). 